\title{
Glycoprotein Hormones Alpha Chain Protein
}

National Cancer Institute

\section{Source}

National Cancer Institute. Glycoprotein Hormones Alpha Chain Protein. NCI Thesaurus.

Code C129842.

Glycoprotein hormones alpha chain (116 aa, $\sim 13 \mathrm{kDa}$ ) is encoded by the human CGA gene. This protein plays a role in hormone signaling. 